\title{
STRUKTUR MODAL, LIKUIDITAS, DAN UKURAN PERUSAHAAN TERHADAP KINERJA KEUANGAN PERUSAHAAN
}

\author{
Ni Luh Gede Sri Fajaryani \\ fajarfajaryani@gmail.com \\ Elly Suryani \\ Fakultas Ekonomi dan Bisnis, Universitas Telkom
}

diterima: 31/1/2018; direvisi: 12/10/2018; diterbitkan: 29/10/2018

\begin{abstract}
This study aims to examine the effect of capital structure as measured by the debt to equity ratio (DER), liquidity measured by the current ratio (CR), and firm size measured by the natural logarithm (Ln) of total assets against financial performance as measured by return on equity (ROE) in companies in the property and real estate sub-sector from 2013-2016. The method of determining the sample used was purposive sampling. The sample used was 40 companies. The data analysis technique used is panel data regression analysis consisting of chow test, hausman test, and lagrange multiplier test using Eviews 9.0 software. The results showed that the capital structure (DER), liquidity (CR), and company size simultaneously had a significant effect on financial performance (ROE). Partially the capital structure (DER) and liquidity (CR) had a significant negative effect on financial performance (ROE). Whereas company size (Ln Total Assets) did not have a significant effect on financial performance (ROE).
\end{abstract}

Keywords: capital structure; liquidity; company size; financial performance

\begin{abstract}
Abstrak
Penelitian ini bertujuan untuk menguji pengaruh struktur modal yang diukur dengan debt to equity ratio (DER), likuiditas yang diukur dengan current ratio (CR), dan ukuran perusahaan yang diukur dengan logaritma natural ( $\mathrm{Ln}$ ) total aset terhadap kinerja keuangan yang diukur dengan return on equity (ROE) pada perusahaan sub sektor properti dan real estate periode 2013-2016. Metode penentuan sampel yang digunakan adalah purposive sampling. Sampel yang digunakan sebanyak 40 perusahaan. Teknik analisis data yang digunakan adalah analisis regresi data panel yang terdiri dari uji chow, uji hausman, dan uji lagrange multiplier dengan menggunakan software Eviews 9.0. Hasil penelitian menunjukkan bahwa struktur modal (DER), likuiditas (CR), dan ukuran perusahaan secara simultan berpengaruh signifikan terhadap kinerja keuangan (ROE). Secara parsial struktur modal (DER) dan likuiditas (CR) memiliki pengaruh signifikan negatif terhadap kinerja keuangan (ROE). Sedangkan ukuran perusahaan (Ln Total Aset) tidak memiliki pengaruhsignifikan terhadap kinerja keuangan (ROE).
\end{abstract}

Kata Kunci: struktur modal; likuiditas; ukuran perusahaan; kinerja keuangan 


\section{PENDAHULUAN}

Pertumbuhan ekonomi yang baik akan dapat membantu meningkatkan profitabilitas perusahaan. Namun, perekonomian di Indonesia kerap kali mengalami perubahan. Hal ini membuat persaingan bisnis semakin kuat untuk mempertahankan eksistensinya. Sehingga, perusahaan terus terpacu untuk meningkatkan kinerjanya masing-masing. Kinerja perusahaan merupakan sesuatu yang dihasilkan oleh perusahaan atas kegiatan operasional yang dilakukan dalam periode waktu tertentu. Payaman Simanjuntak (2005:1) menyatakan bahwa kinerja adalah pencapaian hasil atas pelaksanaan tugas tertentu. Kinerja perusahaan dapat dilihat dari kinerja keuangan perusahaan dalam memperoleh laba. Hal tersebut dapat tercermin dari profitabilitas yang dimiliki perusahaan.Menurut Sartono (2010:122) profitabilitas menunjukkan kemampuan perusahaan dalam menhasilkan laba sehubungan dengan tingkat penjualan, total aset, maupun modal sendiri.

Terdapat fenomena yang terjadi ditahun 2015, dimana perusahaan sub sektor properti dan real estate mengalamin penurunan kinerja yang terlihat dari penurunan laba bersih perusahan. Hal ini diprediksi terus berlanjut sampai tahun 2016. Beberapa perusahaan besar seperti PT. Summarecon Agung Tbk mengalami penurunan laba pada tahun 2016 sebesar $63,55 \%$ dari tahun sebelumnya. Begitu pula dengan PT. Ciputra Development Tbk dan PT. Bumi Serpong Damai Tbk yang juga mengalami penurunan laba bersih masingmasing sebesar $32,41 \%$ dan $15,96 \%$ dari tahun sebelumnya (www.cnnindonesia.com). Penurunan profitabilitas ini tentu akan berdampak pada tingkat pengembalian modal kepada para pemegang saham. Untuk mengukur profitabilitas terhadap ekuitas dapat dilakukan dengan menggunakan rasio keuangan return on equity (Fahmi, 2014:98). Return on equity (ROE) menunjukkan kemampuan perusahaan dalam megelola modal sendiri serta secara efektif mengukur tingkat keuntungan dari investasi yang dilakukan baik oleh pemilik modal sendiri maupun pemegang saham (Sawir, 2009:20).

Dalam memaksimalkan sumber daya untuk meningkatkan kinerja keuangan, perusahaan perlu memperhatikan faktor-faktor internal perusahaannya. Untuk memperoleh laba yang diharapkan, perusahaan membutuhkan dana yang akan dijadikan modal. Pendanaan yang efisien terjadi apabila perusahaan memiliki struktur modal yang baik. Menurut Kamaludin (2011:306) menyatakan bahwa struktur modal menunjukkan bauran sumber pembiayaan jangka panjang. Struktur modal dapat ditunjukan dengan perbandingan antara utang jangka panjang dengan modal sendiri. Untuk mengukur strukur modal guna mengetahui setiap rupiah modal sendiri yang digunakan sebagai jaminan utang dapat menggunakan debt to equity ratio(DER) (Kasmir, 2010:112). Penggunaan utang yang lebih besar sebagai sumber pendanaan dapat meningkatkan risiko yang dtanggung pemegang saham, serta memperbesar tingkat pengembalian investasi. Hal tersebut menunjukkan semakin banyak utang yang dimiliki perusahaan, maka akan dapat menurunkan tingkat likuiditas perusahaan. Menurut Hani (2015:121) likuiditas menunjukkan kemampuan perusahaan dalam memenuhi kewajiban-kewajiban yang segera dapat dicairkan atau yang sudah jatuh tempo. Likuiditas umumnya diukur dengan perbandingan antara aset lancar dengan utang lancar atau yang sering disebut dengan current ratio (CR).

Tingkat aktivitas perusahaan dapat menurun apabila likuiditas yang dimiliki perusahaan terlalu tinggi, hai ini menunjukkan bahwa terdapat banyak dana atau aset yang menganggur. Total aset perusahaan dapat menggambarkan ukuran besar kecilnya suatu perusahaan. Suatu perusahaan dapat dikatakan besar apabila menunjukkan kemampuan mengelola aset maupun penjualan dengan baik untuk memperoleh laba atau profit. Oleh sebab itu, ukuran perusahaan merupakan salah satu faktor yang dapat mempengaruhi kinerja perusahaan. Karena menurut Sartono (2010:249), perusahaan besar akan lebih mudah memasuki pasar modal dan memiliki fleksibilitas yang lebih besar pula dibandingkan dengan perusahaan yang lebih kecil.

Berdasarkan masalah yang telah dipaparkan sebelumnya, makatujuan penelitian ini adalah untuk mengetahui pengaruh struktur modal, likuiditas, ukuran perusahaan baik secara simultan maupun parsial terhadap kinerjakeuangan perusahaan sub sektor properti dan real estate yang terdaftar diBursa Efek Indonesia (BEI) tahun 2013-2016.

Menurut Rudianto (2013:189) kinerja keuangan adalah hasil yang diperoleh manajemen perusahaan ketika menjalankan fungsinya dalam mengelola aset perusahaan secara efektif selama periode tertentu. Kinerja keuangan perusahaan dapat tercermin dari profitabilitas perusahaan.

Rasio profitabilitas menurut Kasmir (2010:115) merupakan rasio untuk menilai kemampuan perusahaan dalam mencari keuntungan. Menurut Fahmi (2014:58) rasio profitabilitas bermanfaat untuk menunjukkan keberhasilan perusahaan di dalam menghasilkan keuntungan. Rasio profitabilitas mengukur efektivitas manajemen secara keseluruhan untu melihat hasil yang diperoleh dalam hubungannya dengan penjualan maupun investasi (Fahmi, 2014:80). Dalam penelitian ini kinerja keuangan diukur menggunakan return on equity (ROE).

Return on equity (ROE) mengkaji sejauh mana suatu perusahaan menggunakan sumber daya yang dimiliki untuk mampu memberikan laba atas ekuitas (Fahmi, 2014:82). ROE dapat dihitung dengan rumus sebagai berikut: 


$$
R O E=\frac{\text { Earning After Tax }(E A T)}{\text { Shareholder's Equity }}
$$

Apabila perusahaan memiliki tingkat return on equity (ROE) yang tinggi maka perusahaan dapat dikatakan memiliki kinerja keuangan yang baik. Hal tersebut berarti, jika tingkat profitabilitas perusahaan tinggi maka kemampuan perusahaan dalam memperoleh laba yang tersedia bagi pemegang saham juga semakin tinggi.

Struktur modal adalah proporsi dalam menentukan pemenuhan kebutuhan belanja perusahaan, di mana dana yang diperoleh menggunakan kombinasi atau panduan sumber yang berasal dari dana jangka panjang yang terdiri dari dua sumber utama, yakni yang berasal dari dalam dan luar perusahaan (Rodoni Ahmad dan Herni Ali, 2010:137). Menurut Sjahrial (2014:213), struktur modal merupakan perimbangan antara penggunaan modal pinjaman yang terdiri dari utang jangka pendek yang bersifat permanen, utang jangka panjang dengan modal sendiri yang terdiri dari saham preferen dan saham biasa. Dalam penelitian ini, struktur modal diukur menggunakan deb to equity ratio (DER).

Debt to equity ratio (DER) merupakan rasio yang digunakan untuk menilai utang dengan ekuitas. Rasio ini dapat dihitung dengan membandingkan seluruh utang dibagi dengan seluruh ekuitas. DER dapat berguna untuk mengetahui jumlah dana yang disediakan peminjam (kreditor) dengan pemilik perusahaan. Dengan kata lain rasio ini digunakan untuk mengetahui setiap rupiah modal sendiri yang dijadikan untuk jaminan utang (Kasmir, 2010:112). Adapun rumus debt to equity ratio adalah:

$$
D E R=\frac{\text { Total Liabilities }}{\text { Total Shareholder }^{\wedge} \text { s Equity }}
$$

Utang diperlukan sebagai tambahan dana untuk mendongkrak kinerja keuangan perusahaan. Suatu perusahaan tidak bisa hanya mengandalkan modal atau ekuitasnya saja. Hal tersebut dapat membuat perusahaan kesulitan untuk melakukan ekspansi bisnis, karena perusahaan membutuhkan dana tambahan untuk dapat memaksimalkan labanya. Hal ini sejalan dengan penelitian Romadhoni (2017) yang menyatakan bahwa debt to equity ratio berpengaruh positif terhadap kinerja keuangan. Sehingga penulis membangun hipotesis 2 (H2) struktur modal memiliki pengaruh signifikan positif terhadap kinerja keuangan.

Likuiditas adalah kemampuan suatu perusahaan memenuhi kewajiban jangka pendeknya secara tepat waktu (Fahmi, 2014:65). Menurut Hani (2015:121) likuiditas merupakan kemampuan suatu perusahaan dalam memenuhi kewajiban-kewajiban keuangan yang segera dapat dicairkan atau yang sudah jatuh tempo. Secara spesifik likuiditas mencerminkan ketersediaan dana yang dimiliki perusahaan guna memenuhi semua utang yang akan jatuh tempo.
Kasmir (2010:111) rasio lancar atau current ratio merupakan rasio untuk mengukur kemampuan perusahaan membayar kewajiban jangka pendek atau utang yang segera jatuh tempo pada saat ditagih secara keseluruhan. Adapun untuk menghitung current ratio (CR) menurut Fahmi (2014:66) adalah sebagai berikut:

$$
C R=\frac{\text { Current Assets }}{\text { Current Liabilities }}
$$

Nilai current ratio yang tinggi, berarti perusahaan memiliki kemampuan untuk memenuhi kewajibankewajiban lancarnya. Namun, apabila current ratio perusahaan terlalu tinggi, maka dapat berdampak tidak baik pada tingkat laba yang diperoleh. Oleh sebab itu, perusahaan perlu menjaga tingkat likuiditas perusahaannya. Hal ini sejalan dengan penelitian Mujtahidah dan Laily (2016) yang menyatakan bahwa current ratio berpengaruh negatif terhadap return on equity. Sehingga penulis membangun hipotesis $3(\mathrm{H} 3)$ yaitu likuiditas memiliki pengaruh signifikan negatif terhadap kinerja keuangan perusahaan.

Menurut Sartono (2010:249) ukuran perusahaan adalah perusahaan besar yang sudah well established di mana perusahaan tersebut akan lebih mudah untuk memperoleh modal di pasar modal dibandingkan dengan perusahaan kecil. Hal tersebut berarti perusahaan besar memiliki fleksibibilitas yang lebih besar dibandingkan dengan perusahaan kecil.

Dalam penelitian ini ukuran perusahaan dihitung dengan menggunakan indikator total aset. Menurut Harahap (2013:23), menyatakan pengukuran perusahaan menggunakan total aset berdasarkan pertimbangan bahwa total aset mencerminkan ukuran perusahaan serta dianggap mempengaruhi ketepatan waktu. Menurut Kurniasih (2012:150) rumus untuk mengukur ukuran perusahaan menggunakan total aset adalah:

$$
\text { Ukuran Perusahaan }=\text { Ln Total Aset }
$$

Besarnya jumlah aset yang dimiliki perusahaan, berarti semakin besar juga dana yang dikelola. Perusahaan dengan jumlah aset yang besar dapat dikatakan sebagai perusahaan yang mapan. Suatu perusahaan yang mapan, akan lebih mudah untuk memasuki pasar modal dan memiliki fleksibilitas yang lebih besar pula dibandingkan dengan perusahaan yang lebih kecil. Apabila perusahaan mengelola asetnya dengan baik maka hal tersebut dapat membantu meningkatkan kinerja perusahaan. Hal tersebut sejalan dengan penelitian Kusumaningtyas (2016) yang menyatakan bahwa ukuran perusahaan berpengaruh positif terhadap kinerja keuangan. Sehingga penulis membangun hipotesis $4(\mathrm{H} 4)$ yaitu ukuran perusahaan memiliki pengaruh signifikan positif terhadap kinerja keuangan. 


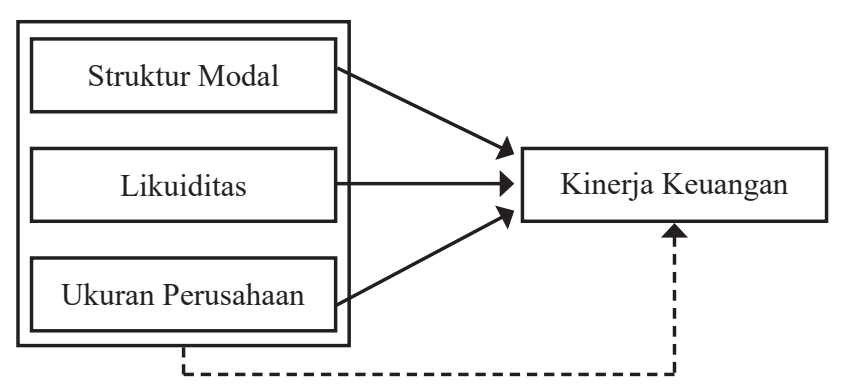

Keterangan:

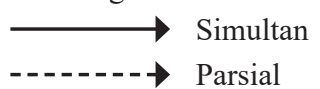

Gambar 1, Kerangka Pemikiran

\section{METODE}

Jenis penelitian yang digunakan pada penelitian ini adalah penelitian deskriptif verifikatif yang bersifat kausalitas. Dalam penelitian ini menggunakan metode data kuantitatif yaitu data dalam bentuk bilangan. Populasi penelitian adalah perusahaan sub sektor properti dan real estate yang terdaftar di Bursa Efek Indonesia periode 2013-2016. Penelitian ini menggunakan teknik purposive sampling dalam menentukan kriteria sampel. Sampel yang digunakan sebanyak 40 perusahaan dengan waktu penelitian selama 4 tahun. Data pada penelitian ini sebanyak 160 data. Metode analisis yang digunakan adalah analisis regresi data panel.

\section{HASIL DAN PEMBAHASAN}

Penelitian ini menggunakan variabel independen yaitu struktur modal (DER), likuiditas (CR), dan ukuran perusahaan (Ln Total Aset). Dan variabel dependen yaitu Kinerja Keuangan (ROE). Hasil analisis deskriptif masing-masing variabel ditunjukkan pada Tabel 1.

Tabel 1. Hasil Uji Statistik Deskriptif

\begin{tabular}{lrrrr}
\hline & DER (\%) & \multicolumn{1}{c}{ CR (\%) } & Ln Total Aset & ROE (\%) \\
\hline Mean & 71,648 & 263,216 & 28,838 & 10,222 \\
Median & 61,259 & 184,567 & 28,990 & 9,090 \\
Maximum & 224,187 & $1.906,741$ & 31,451 & 41,163 \\
Minimum & 3,469 & 20,773 & 25,162 & $-15,219$ \\
Std. Dev. & 48,424 & 275,578 & 1,479 & 10,421 \\
\hline
\end{tabular}

Uji Chow memiliki tujuan untuk menguji metode yang lebih tepat untuk digunakan diantara Common Effect Method dan Fixed Effect Method. Berdasarkan Tabel 3.2 di atas menunjukkan hasil pengujian dari Uji Chow, diperoleh nilai probability (Prob.) cross section F sebesar 0,0400. Nilai tersebut lebih kecil daripada tingkat signifikansi 5\%. Oleh karena itu, berdasarkan ketentuan pengambilan keputusan, maka hipotesis Ho ditolak sehingga metode yang dipilih adalah Fixed
Effect Method. Berikutnya, akan dilakukan pengujian selanjutnya yaitu Uji Hausman.

Uji Hausman memiliki tujuan untuk menguji metode yang lebih tepat untuk digunakan antara Random Effect Method dan Fixed Effect Method. Tabel 1 menunjukkan hasil pengujian dari Uji Hausman, diperoleh nilai probability (Prob.) cross section random sebesar 0,8857 . Nilai tersebut berarti lebih besar daripada tingkat signifikansi 5\%. Oleh karena itu, berdasarkan ketentuan pengambilan keputusan, maka hipotesis Ho diterima sehingga metode yang digunakan yaitu Random Effect Method. Kemudian, dilakukan pengujian selanjutnya yaitu Uji Lagrange Multiplier.

Uji Lagrange Multiplier memiliki tujuan untuk menguji metode yang lebih tepat untuk digunakan yaitu antara Common Effect Method dan Random Effect Method. Tabel 2 menunjukkan hasil pengujian dari Uji Lagrange Multiplier, diperoleh nilai cross section pada Breusch-Pagan sebesar 0,0541. Nilai tersebut lebih besar dari tingkat signifikansi sebesar 5\%, sehingga metode yang tepat digunakan yaitu Common Effect Method. Metode ini merupakan metode yang digunakan untuk menganalisa pengaruh struktur modal, likuiditas, dan ukuran perusahaan terhadap kinerja keuangan perusahaan.

Berdasarkan Tabel 2, hasil pengujian pada penelitian ini menunjukkan nilai uji statistik $F$ sebesar 0,000079 yang berarti bahwa nilai tersebut lebih kecil daripada nilai tingkat signifikansi sebesar 5\%. Dari nilai tersebut dapat disimpulkan bahwa struktur modal (DER), likuiditas (CR), dan ukuran perusahaan (Ln Total Aset) secara simultan memiliki pengaruh yang signifikan terhadap kinerja keuangan (ROE) perusahaan. Dalam penelitian ini didapatkan hasil koefisien determinasi $\left(\mathrm{R}^{2}\right)$ sebesar 0,112123 atau $11,2123 \%$. Nilai ini menunjukkan bahwa struktur modal (DER), likuditas (CR), dan ukuran perusahaan (Ln Total Aset) berpengaruh sebesar 11,2123\% terhadap kinerja keuangan (ROE) perusahaan. Sedangkan sisanya dipengaruhi oleh variabel lain.

Berdasarkan hasil pengujian pada Tabel 2, dapat diperoleh hasil sebagai berikut:

$$
\begin{aligned}
\mathrm{ROE}= & 0,087456-0,000829(\mathrm{DER})-0,00215(\mathrm{CR}) \\
& +0,00463(\text { Ln Total Aset })+\varepsilon
\end{aligned}
$$

Keterangan :

$$
\begin{array}{ll}
\text { ROE } & =\text { Return On Equity } \\
\text { DER } & =\text { Debt to Equity Ratio } \\
\text { CR } & =\text { Current Ratio } \\
\text { LNTA } & =\text { Ln Total Aset } \\
\alpha & =\text { Konstanta } \\
\beta 1, \beta 2, \beta 3 & =\text { Koefisien regresi masing-masing variabel } \\
\varepsilon & =\text { error term }
\end{array}
$$

Nilai koefisien DER sebesar -0,000829 yang berarti bahwa jika nilai struktur modal (DER) meningkat sebesar 
1 satuan dan variabel lainnya konstan, maka nilai variabel dependen kinerja keuangan (ROE) akan menurun sebesar 0.000829. Hubungan struktur modal (DER) dan kinerja keuangan (ROE) dapat dilihat dari nilai probability sebesar 0,0002, yang berarti nilai probability lebih kecil dibandingkan dengan tingkat signifikansi sebesar $5 \%$, dengan koefisien sebesar $-0,000829$. Nilai ini menunjukkan bahwa Ha ditolak, karena memiliki arah yang berlawanan dengan hipotesis. Maka, struktur modal (DER) memiliki pengaruh signifikan negatif terhadap kinerja keuangan (ROE) perusahaan.

Nilai koefisien CR sebesar -0,00215 yang berarti bahwa jika nilai likuiditas (CR) meningkat sebesar 1 satuan dan variabel lainnya konstan, maka nilai variabel dependen kinerja keuangan (ROE) akan menurun sebesar 0,00215.Hubungan likuiditas (CR) dan kinerja keuangan (ROE) dapat dilihat dari nilai probability sebesar 0,0001, yang berarti nilai probability lebih kecil dibandingkan dengan tingkat signifikansi sebesar $5 \%$, dengan koefisien sebesar $-0,000215$. Nilai ini menunjukkan bahwa Ho ditolak, maka likuiditas (CR) memiliki pengaruh signifikan negatif terhadap kinerja keuangan (ROE) perusahaan.

Nilai koefisien Ln Total Aset sebesar 0,00463 yang berarti bahwa jika nilai ukuran perusahaan (Ln total Aset) meningkat sebesar 1 satuan dan variabel lainnya konstan, maka nilai variabel dependen kinerja keuangan (ROE) akan meningkat sebesar 0,00463.Hubungan ukuran perusahaan (Ln Total aset) dan kinerja keuangan (ROE) dapat dilihat dari nilai probability sebesar 0,5334 , yang berarti nilai probability lebih besar dibandingkan dengan tingkat signifikansi sebesar 5\%, dengan koefisien sebesar 0,004632. Nilai ini menunjukkan bahwa Ho diterima, maka ukuran perusahaan (Ln Total Aset) tidak memiliki pengaruh signifikan terhadap kinerja keuangan (ROE) perusahaan.

\section{KESIMPULAN}

Penelitian ini bertujuan untuk menganalisis pengaruh variabel struktur modal, likuiditas, dan ukuran perusahaan terhadap kinerja keuangan perusahaan. Objek pada penelitian ini adalah perusahaan sub sektor properti dan real estate yang terdaftar di Bursa Efek Indonesia tahun 2013-2016. Penelitian ini menggunakan 40 sampel perusahaan dan runtut waktu selama 4 tahun. Jumlah data yang digunakan dalam penelitian ini adalah sebanyak 160. Berdasarkan penelitian yang telah dilakukan, diperoleh kesimpulan sebagai berikut: (1) Secara deskriptif dapat disimpulkan sebagai berikut : (a) Struktur modal memiliki nilai rata-rata sebesar $71,648 \%$ dengan nilai median sebesar $61,259 \%$. Serta memiliki standar deviasi sebesar $48,424 \%$, dimana nilai rata-rata lebih besar dari standar deviasi sehingga dapat dikatakan bahwa data struktur modal bersifat berkelompok. Hasil ini menunjukkan sebagian besar perusahaan sub sektor properti dan real estate menggunakan komposisi struktur modal yang lebih besar berasal dari utang dibandingkan dengan modal sendiri. (b) Likuiditas memiliki nilai rata-rata sebesar 263,216\% dengan nilai median sebesar $184,567 \%$. Serta memiliki standar deviasi sebesar $275,578 \%$, dimana nilai rata-rata lebih kecil dari standar deviasi sehingga dapat dikatakan bahwa data likuiditas bersifat bervariasi. Hasil ini menunjukkan sebagian besar perusahaan sub sektor properti dan real estate sudah mampu memenuhi kewajiban jangka pendeknya secara tepat waktu. (c) Ukuran perusahaan memiliki nilai rata-rata sebesar 28,838 dengan nilai median sebesar 28,990. Serta memiliki standar deviasi sebesar 1,479 , dimana nilai rata-rata lebih besar dari standar deviasi sehingga dapat dikatakan bahwa data struktur modal bersifat berkelompok. Hasil ini menunjukkan semua perusahaan sub sektor properti dan real estate berada pada klasifikasi perusahaan yang besar.Kinerja keuangan memiliki nilai rata-rata sebesar 10,222\% dengan nilai median sebesar $9,090 \%$. Serta memiliki standar deviasi sebesar 10,421\%, dimana nilai rata-rata lebih kecil dari standar deviasi sehingga dapat dikatakan bahwa data struktur modal bersifat bervariasi. Hasil ini menunjukkan sebagain besar perusahaan sub sektor properti dan real estate mampu dalam memperoleh laba bagi para pemegang saham guna memenuhi kewajibankewajibannya. (2) Variabel struktur modal (DER), likuiditas (CR), dan ukuran perusahaan (Ln Total Aset) secara simultan berpengaruh signifikan terhadap kinerja keuangan perusahaan sub sektor properti dan real estate yang terdaftar di Bursa Efek Indonesia periode 2013-2016. Serta memiliki nilai koefisien determinasi sebesar 0,112123 yang menunjukkan bahwa struktur modal, likuiditas, dan ukuran perusahaan berpengaruh $11,2123 \%$ terhadap kinerja keuangan dan sisanya dipengaruhi oleh variabel lain. (3) Secara parsial, struktur modal yang diukur menggunakan debt to equity ratio memiliki pengaruh signifikan negatif terhadap kinerja keuangan perusahaan sub sektor properti dan real estate yang terdaftar di Bursa Efek Indonesia periode 2013-2016. Hasil ini menunjukkan bahwa semakin tinggi nilai debt to equity ratio yang dimiliki perusahaan dapat meningkatkan resiko penurunan laba akibat beban-beban atas pinjaman yang dilakukan. (4) Secara parsial, likuditas yang diukur menggunakan current ratio memiliki pengaruh signifikan negatif terhadap kinerja keuangan perusahaan sub sektor properti dan real estate yang terdaftar di Bursa Efek Indonesia periode 2013-2016. Hasil ini menunjukkan bahwa peningkatan current ratio berbanding terbalik dengan laba yang diperoleh. (5) Secara parsial, ukuran perusahaan yang diukur menggunakan Ln total aset tidak memiliki pengaruh signifikan terhadap kinerja keuangan perusahaan sub sektor properti dan real estate yang terdaftar di Bursa Efek Indonesia periode 20132016. Hasil ini menunjukkan bahwa besar kecilnya jumlah aset yang dimiliki tidak dapat memprediksi jumlah laba yang dihasilkan. 


\section{REFERENCES}

Audriene, D. 2017. Mencermati Emiten Properti setelah Lesu di Tahun Lalu. [Online] Available at : https://www.cnnindonesia.com/ ekonomi/20170331110511-92-204001/mencermatiemiten-properti setelah-lesu-di-tahun-lalu/ [Accessed at 10 Oktober 2017]

Fahmi, I. 2014. Pengantar Manajemen Keuangan (3rd ed.). Bandung: Alfabeta.

Hani, S. 2015. Teknik Analisa Laporan Keuangan. Medan: UMSU PRESS.

Harahap, S. S. 2013. Analisis Kritis Atas Laporan Keuangan (Cetakan Kesebelas). Jakarta: Rajawali Pers.

Kamaludin. 2011. Mannajemen Keuangan (1st ed.). Bandung: Mandar Maju.

Kasmir. 2010. Pengantar Manajemen Keuangan. Jakarta: Kencana Prenada Media Group.

Kurniasari, Desi. 2014. Faktor-Faktor Terkait KAP Switching Yang Dilakukan Perusahaan Secara Voluntary. Fakultas Ekonomi Dan Bisnis Universitas Dian Nuswantoro.

Kusumaningtyas, A. 2016. Pengaruh arus Kas Operasi, Struktur Kepemilikan dan ukuran Perusahaan terhadap Kinerja Keuangan. Jurnal Ilmu dan Riset Akuntansi: Volume 5, Nomor 2, 15-16

Mujtahidah, I., \& Laily, N. 2016. Pengaruh Rasio Likuiditas, Rasio Aktivitas dan Rasio Solvabilitas terhadap Profitabilitas. Jurnal Ilmu dan Riset Manajemen: Volume 5, Nomor 11, November 2016.

Rodoni, A. dan Ali, H. 2010. Manajemen Keuangan. Jakarta: Mitra Wacana Media.

Romadhoni, R. and Sunaryo, H., 2017. Pengaruh Struktur Modal terhadap Kinerja Keuangan Perusahaan Manufaktur Sektor Makanan dan Minuman yang terdaftar di Bursa Efek Indonesia Tahun 2013-2016. Jurnal Ilmiah Riset Manajemen, 6(06).

Rudianto. 2013. Akuntansi Manajemen Informasi untuk Pengambilan Keputusan Strategis. Jakarta: Erlangga.

Sartono, A. 2010. Manajemen Keuangan Teori dan Aplikasi (Edisi 4). Yogyakarta: BPFE.

Sawir, A. 2009. Analisa Kinerja Keuangan dan Perencanaan Keuangan Perusahaan, Jakarta : PT. Gramedia Pustaka Utama.

Simanjuntak, P. J. 2005. Manajemen Sumber Daya Manusia. Jakarta: FE UI.

Sjahrial, D. 2014. Manajemen Keuangan Lanjutan (Edisi Pertama). Jakarta: Mitra Wacana Media.

Tabel 2. Hasil Uji Regresi Data Panel

\begin{tabular}{|c|c|c|c|c|c|}
\hline & Prob. & Prob. (F-Statistic) & Cross-Section & R-Squared & Coeficient \\
\hline Uji Chow (Cross Section F) & 0,0400 & - & - & - & - \\
\hline Uji Hausman (Cross Section Random) & 0,8857 & - & - & - & - \\
\hline Uji Lagrange Multiplier (Breusch Pagan) & - & - & 0,0541 & - & - \\
\hline Uji Simultan (Uji F) & - & 0,000079 & - & 0,112123 & - \\
\hline Uji Parsial (Uji t), Common Effect Method & - & - & - & - & - \\
\hline Struktur Modal (DER) & 0,0002 & - & - & - & $-0,000829$ \\
\hline Likuiditas (CR) & 0,0001 & - & - & - & $-0,000215$ \\
\hline Ukuran Perusahaan (LN Total Aset) & 0,5334 & - & - & - & 0,004632 \\
\hline
\end{tabular}

